\title{
IMPACT OF SUPPLEMENTATION WITH DIFFERENT PROTEIN SOURCES ON THE PARASITOLOGICAL PROFILE OF OVINE MATRICES AND DEVELOPMENT OF LAMBS
}

\author{
IMPACTO DA SUPLEMENTAÇÃO COM DIFERENTES FONTES PROTEICAS NO \\ PERFIL PARASITOLÓGICO DE MATRIZES OVINAS E NO DESENVOLVIMENTO \\ DOS CORDEIROS
}

\author{
Antonio Leandro Chaves GURGEL ${ }^{1 *}$; Gelson dos Santos DIFANTE ${ }^{1}$; \\ João Virgínio EMERENCIANO NETO²; Francisca Fernanda da Silva ROBERTO 3 ; \\ Lilian Gioto ZAROS ${ }^{4}$; Marcone Geraldo COSTA $^{5}$; Luis Carlos Vinhas ÍTAVO ${ }^{1}$; \\ Camila Celeste Brandão Ferreira ÍTAVO ${ }^{1}$
}

1. Universidade Federal de Mato Grosso do Sul, Faculdade de Medicina Veterinária e Zootecnia, Campo Grande - MS, Brasil; 2. Universidade Federal do Vale do São Francisco, Campus de Ciências Agrárias, Petrolina, PE, Brasil; 3. Universidade Federal da Paraíba, Campus de Ciências Agrarias, Areia - PB, Brasil; 4. Universidade Federal do Rio Grande do Norte, Departamento de Microbiologia e Parasitologia, Natal-RN, Brasil; 5. Universidade Federal do Rio Grande do Norte, Unidade Acadêmica Especializada em Ciências Agrárias, Macaíba, RN, Brasil. *antonioleandro09@gmail.com

\begin{abstract}
The aim was to evaluate the impact of supplementation with different protein sources from agro-industrial production on the parasitological profile of ovine matrices and the development of their offspring. The protein sources used were: soybean bran, cotton pie, babassu pie, and coconut pie. A total of 60 ovine matrices were used, with confirmed pregnancy and supplemented in the final third of gestation at $0.5 \%$ of live weight in pastures of deferred Marandu grass. The evaluations occurred from the final third of gestation and in the lactation phase until weaning. The data collected in the matrices were: counting of eggs per gram of feces (EPG) and identification of infective larvae (Faecal test), evaluation of the degree of anemia by the FAMACHA $^{\odot}$ method, body weight $(\mathrm{kg})$, and body condition score (BCS). In the lambs, the biometric measurements were taken from the 30 days of life until weaning. In Faecal test, the prevalence was $98 \%$ of Haemonchus spp. There was no effect of the protein sources for EPG (3476.0) and FAMACHA ${ }^{\odot}$. However, in the mats supplemented with coconut pie were observed the lowest body weights (36.9 kg) and lower BCS (2.7). Babassu, coconut and cotton cakes, and soybean meal used as a protein source in the supplementation of ovine matrices kept in deferred pastures of Marandu grass at the $0.5 \%$ level of live weight maintain the production indexes consistent with the physiology stage of the matrices even with a high endo-parasitic load.
\end{abstract}

KEYWORDS: Helminth control. Nutrition. EPG. Ovine breeding. Periparturient.

\section{INTRODUCTION}

Sheep breeding for meat production has expanded in the last decade, mainly due to the increase in the demand for sheep meat in the market. For this reason, there has been a search for production systems able to produce, efficiently, quality meat at low cost (MELO et al., 2017; FERNANDES et al., 2017; TRINDADE et al., 2018; EMERENCIANO NETO et al., 2018). Even the same, the production chain of these animals in Brazil is still incipient since this activity in most properties is considered as secondary.

The poor performance is justified by the fact that the ideal conditions of forage cultivation and forage production of tropical forage grasses in Brazil are not constant throughout the year, mainly due to periods of low rainfall or other abiotic factors. These conditions justify the use of pasture management techniques such as deferral, which consists in selecting a pasture area of the property and exclude grazing, usually at the end of the rainy season, so that forage accumulation occurs to be grazed during the dry period (SANTOS et al., 2014).

Another relevant fact concerns health management, more precisely gastrointestinal endoparasites, that is one of the main restriction of grazing systems based on small ruminants (GAUDIN et al., 2018). which cause growth retardment, weight loss, decrease in forage intake, milk production, fertility and increased cases of anemia and diarrhea in animals (ROSALINSKIMORAES et al., 2012; SANTOS et al., 2017). The cases of mixed and massive infections lead the animal to death, especially in pregnant or lactating 
matrices that during this period present immunosuppression due to the increase in nutritional requirements (ROSALINSKI-MORAES et al., 2012; BEASLEY et al., 2012; GAUDIN et al., 2018). The use of anthelmintics treatments in the control of gastrointestinal parasites in sheep provides pressure for the selection of resistant genotypes in parasite populations (KAHN et al., 2003).

In addition, tropical forage grass in most cases, when used as an exclusive source in the ruminant diet, do not meet the requirements of the species, even during periods of higher forage production, which may compromise animal performance (NRC, 2007). Thus, there is need to establish nutrient supply strategies to increase the energetic/protein density of the diet to minimize the seasonal effects of forage production and high endoparasite load on pregnant or lactating females (ROCHA et al., 2011).

Supplementation get in the system in order to correct nutritional deficiencies, and in sheep production, it minimizes the impact of endoparasitosis (HOUDIJK et al., 2009; ROCHA et al., 2011; TORRES-ACOSTA et al., 2012; MELO et al., 2017). The constant search for alternative feeds to the soybean bran, which is the most used protein concentrate in animal production systems, is fundamental, especially in regions distant from those producing grain.

Among the available industrial waste with the potential to be used in animal feed are cottonseed and babassu (ABDALLA et al., 2008), and coconut pie, which in addition to presenting themselves as potential food in ruminant nutrition, if used, avoid the incorrect disposal in the environment and minimizes on several fronts the environmental impact of animal production and industry.

However, little information is available on the use of these residues in supplementation of grazing matrices, and whether they are capable of supplying nutrients to the animals without compromising the development of the matrix, the fetus and later the offspring, given the immunological fragility of these animals during gestation and lactation (ROCHA et al., 2011; BEASLEY et al., 2012). Given the above, this study aimed to evaluate the impact of supplementation with different protein sources from agro-industrial production on the parasitological profile of ovine matrices and the development of their offspring.

\section{MATERIAL AND METHODS}

\section{Location and experimental period}

The test was carried out at the Agricultural Research Group (GEFOR), located in the Specialized Academic Unit of Agricultural Sciences, belonging to the Federal University of Rio Grande do Norte - UFRN in Macaíba, RN, in the East Potiguar mesoregion ( $5^{\circ} 53$ " 35.12 ' South and $35^{\circ} 21$ " 47.03 ' West). The climate of the region is characterized as dry sub-humid (Thornthwaite, 1948), during the experimental period, from November 2016 to January 2017, accumulated rainfall was $70 \mathrm{~mm}$ and the average temperature of $28{ }^{\circ} \mathrm{C}$ (INMET, 2017).

\section{Animals}

Sixty Santa Inês sheep aged between two and four years with an initial mean weight of $44.9 \pm$ $4.0 \mathrm{~kg}$ breeders were submitted to a mating season of 45 days, with a male / female ratio of one breeder per 30 ewes. Pregnancy was diagnosed by ultrasound 45 days after the end of the reproductive season, and no anthelmintic treatment was used after the pregnancy was confirmed. Of the 60 exposed breeding ewes, 68 lambs were weaned at 60 days of age, with an average weight of $17.44 \pm 3.3 \mathrm{~kg}$.

\section{Experimental design}

After the diagnosis of pregnancy, the ewes were allocated on deferred grazing of Brachiaria brizantha cv. Marandu. In the final third of the gestation were distributed in a completely randomized design, with measures repeated over time, with four treatments and 15 repetitions. The treatments were the protein sources used in the supplements: babassu pie, cotton pie, coconut pie, and soybean bran. All evaluations occurred in the last month of gestation (November) and during lactation (December and January) until weaning, at 14-day intervals, characterizing measures repeated over time.

\section{Feed Management}

The matrices were maintained during the day ( 7 to 16 hours) in deferred pastures of Brachiaria brizantha cv. Marandu and separated for collective stalls at night. In the final third of gestation, they began to receive concentrated protein/energy supplement fixed at $0.5 \%$ of the live weight. The energy source used was corn. The supplements were iso-nitrogenated (Table 1) and formulated to meet the requirements of the matrices, according to NRC recommendations 2007. 
Table 1. Percentage of supplementation for the matrices in the final third of gestation until weaning and lambs in the growth phase

\begin{tabular}{|c|c|c|c|c|c|c|c|c|}
\hline & $\begin{array}{l}\text { Ground } \\
(\%)\end{array}$ & Corn & $\begin{array}{l}\text { Protein } \\
(\%)^{*}\end{array}$ & source & $\begin{array}{l}\text { Mineral } \\
(\%)\end{array}$ & Supplement & $\begin{array}{l}\text { Urea } \\
(\%)\end{array}$ & $\begin{array}{ll}\text { Soy } & \text { oil } \\
(\%) & \\
\end{array}$ \\
\hline Soy concentrate & 80.5 & & 14.6 & & 1.2 & & 3.7 & - \\
\hline Cotton concentrate & 72.5 & & 22.1 & & 1.2 & & 4.2 & - \\
\hline Babassu concentrate & 70.9 & & 22.9 & & 1.2 & & 5.0 & - \\
\hline Coconut concentrate & 68.3 & & 25.5 & & 1.2 & & 5.0 & - \\
\hline Concentrate of lambs & 66.0 & & $29.5 * *$ & & 3.0 & & - & 1.5 \\
\hline
\end{tabular}

* protein source according to the treatment (soybean, cotton, babassu, and coconut).** soybean bran.

Table 2. Chemical composition of the ingredients used to formulate the diets of the ewes in the final third of gestation until weaning and lambs in the growing phase.

\begin{tabular}{llllll}
\hline \multirow{2}{*}{ Variable $\left(\mathrm{g} \mathrm{kg}^{-1}\right)$} & Ingredients & & & \\
\cline { 2 - 6 } & Soybean & Babassu & Coconut & Cotton & Corn \\
\hline Dry mater & 837.5 & 897.8 & 872.8 & 844.6 & 840.9 \\
Mineral matter & 63.1 & 48.9 & 35.0 & 45.1 & 8.5 \\
Organic matter & 936.9 & 951.1 & 965.0 & 954.9 & 991.5 \\
Crude protein & 477.8 & 168.9 & 160.2 & 286.4 & 74.3 \\
Ether extract & 25.5 & 71.7 & 275.1 & 45.5 & 50.5 \\
Neutral detergent fiber & 169.5 & 515.8 & 447.2 & 413.1 & 65.0 \\
Acid detergent fiber & 93.7 & 311.8 & 301.0 & 266.7 & 37.7 \\
Lignin & 4.3 & 92.4 & 97.0 & 83.7 & 7.1 \\
\hline
\end{tabular}

After lambing, the matrices and their offspring were kept on maternity picket for seven days. After this period, the lambs were kept during the day (from 7 to 16 hours) in pastures separated from the mothers and managed in the controlled feeding system. The lambs were supplemented with concentrate (Table 1) formulated to meet the requirements of growing lambs (NRC, 2007) with consumption ad libitum, for which the leftovers were kept around $10 \%$.

\section{Parasitic burden}

The parasitological analyzes were performed by counting eggs per gram of feces (EPG), according to the technique described by Gordon and Withlock (1939) modified by Ueno and Gonçalves (1989). The stool samples were collected directly from the animals' rectal bulb and placed in plastic bags, sterile, duly identified, and conditioned in isothermal boxes for transportation to the laboratory for processing.

Stool cultures were performed from a pool of samples from each group, following the method described by Roberts and O'Sullivan (1950). The infective larvae obtained were identified according to the morphological characteristics described by Keith (1953).

\section{Degree of anemia}

The degree of anemia of the matrices was evaluated by the FAMACHA $^{\odot}$ method, using visualization of the ocular mucosa color, with a score of 1 to 5, according to coloration (bright red and white, respectively). Animals with grade FAMACHA $^{\odot} 1$ or 2 are considered healthy, and with FAMACHA $^{\odot} 3$ or more are considered anemic (VAN WYK; BATH, 2002).

\section{Body weight and body condition score}

On the same day of fecal collection, the animals were weighed and evaluated individually for body condition score (BCS). BCS evaluations were performed by palpating the dorsal region of the spine of the sheep (RUSSEL et al., 1969). In this way, values from 1 to 5 were assigned, in intervals of 0.5 where 1 represented a very lean animal and 5 a very fat animal.

\section{Biometric measurements in sheep}

The biometric measurements of the lambs were performed from the 30 days of life with the aid of a measuring flexible tape and a ruler adapted for height measurement, with the animals arranged on a flat surface. Body length (measured between the 
base of the neck and the tail insertion), height at withers, rump height, chest width, croup width, girth thoracic and girth abdomen were measured as demonstrated by Cezar and Sousa (2007).

\section{Statistical analyses}

All variables were submitted to the Shapiro-

Wilker test to verify normality characteristics. Because the variable EPG count did not have such characteristics, it was converted using $\log ^{10}(x+1)$. The data related to the matrices were submitted to the variance analysis following the model: Yijk $=\mu$ $+\mathrm{Pi}+\alpha \mathrm{ij}+\mathrm{Fk}+(\mathrm{P} * \mathrm{~F}) \mathrm{ik}+\beta \mathrm{ijk} ; \mathrm{Yijk}=$ value observed at protein source $\mathrm{i}$, repetition $\mathrm{j}$, physiological phase $\mathrm{k} ; \mu=$ general average effect; $\mathrm{Pi}$ = effect of protein source $\mathrm{i}, \mathrm{i}=$ soybean, coconut, cotton, and babassu; $\alpha \mathrm{ij}=$ effect of the random error attributed to the plot; $\mathrm{Fk}=$ effect of physiological stage $\mathrm{k}, \mathrm{k}=$ final third of gestation, lactation and weaning, (DP) $\mathrm{ik}=$ effect of interaction between protein source and physiological stage; $\beta \mathrm{ijk}=$ random error attributed to the subplot. In the biometrics data of the lambs, the fixed effect that composed the model was of the different protein sources used in the diets of the matrices.

When meaningful by the F test, the effect of the sources of variation and their interactions were analyzed by the Tukey test, at 5\% of significance. In order to estimate the correlation between the variables: live weight, body condition score, anemia degree and eggs per gram of faeces, the Pearson correlation test was used, with a significance of 5\% $(P<0,05)$.

\section{RESULTS}

There was no interaction between the protein sources and the physiological phases of the matrices $(\mathrm{P}>0.05)$ for the evaluated variables, so the effects of protein sources and the physiological phases of the matrices were presented independently.

\section{Identification of infective larvae}

The identification of infective larvae (L3), revealed a mixed infection with the presence of the following genera of nematodes: Haemonchus spp., Strongyloides spp., Trichostrongylus spp., and Oesophagostomum spp. Haemonchus spp. was the most prevalent nematode in the herd with an average prevalence of $98 \%$ regardless of the protein source provided and the physiological phase of the matrices. The prevalence of infection by other species of nematodes in the herd was $2 \%$.

\section{Egg count per gram of feces}

Protein sources did not affect EPG counts $(\mathrm{P}=0.5877)$. Although the ewes had high EPF 3476.0 eggs/gram of feces, independently of the protein source, these values were significantly $(\mathrm{P}=$ 0.0397) lower when the matrices were in the final third of gestation, higher during lactation and intermediates at weaning (Figure 1).

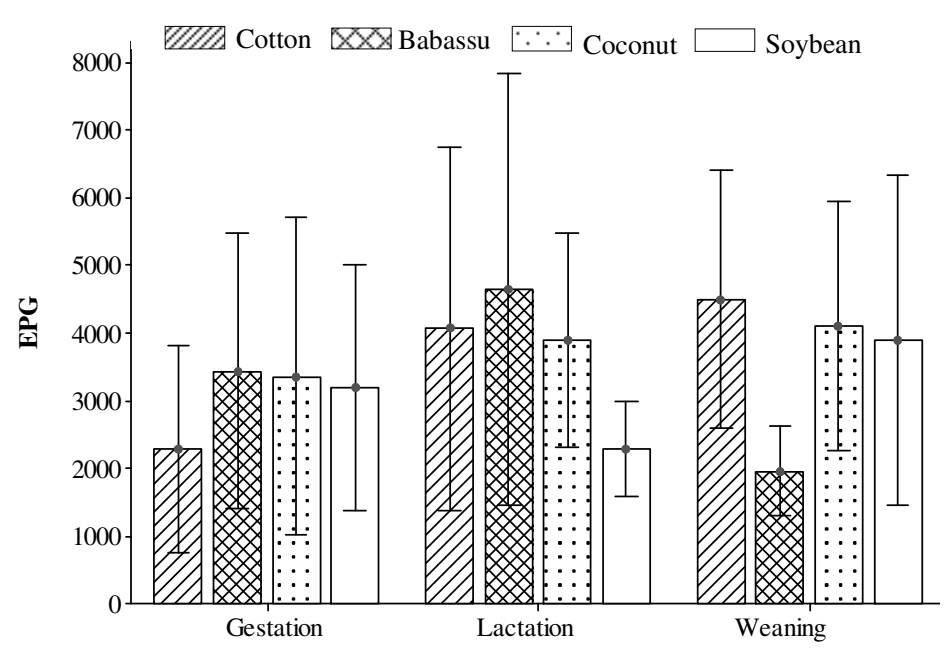

Figure 1. Egg counts per gram of feces (EPG) of ovine matrices in different physiological stages maintained in deferred pasture and supplemented with different protein sources. 


\section{Degree of anemia}

The degree of anemia was not influenced by the different protein sources used in the supplements $(\mathrm{P}=0.7075)$. It was also not altered $(\mathrm{P}=0.5276)$ during the different physiological stages of the matrices (Figure 2). The animals were classified as anemic (FAMACHAC)/= 3) independently of the protein source provided and the physiological stage of the matrices.

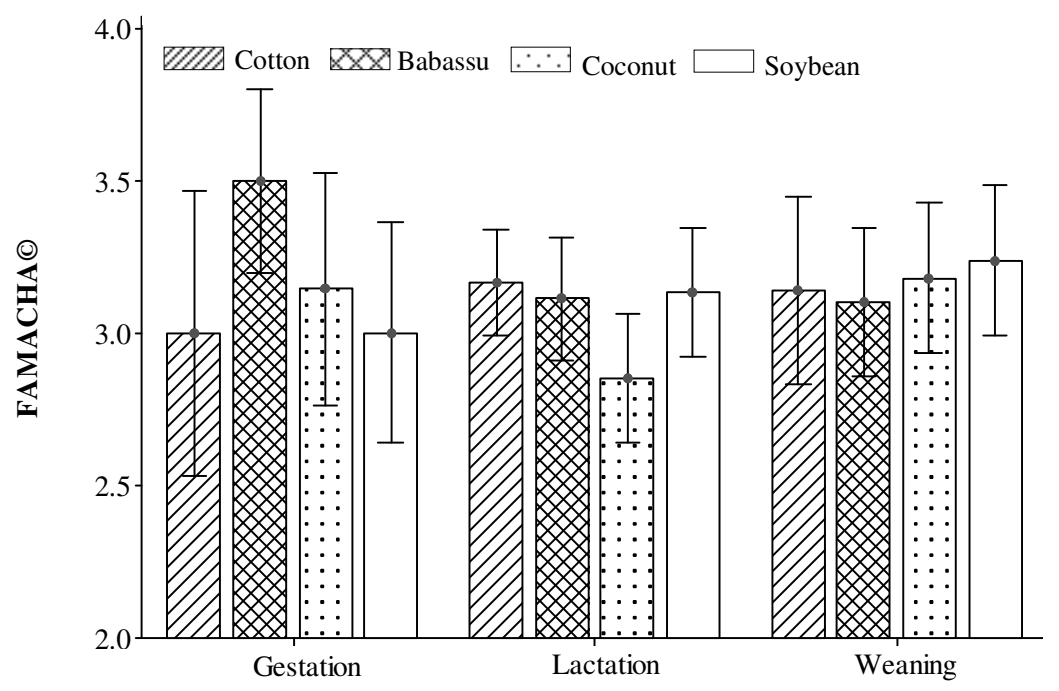

Figure 2. Degree of anemia $\left(\mathrm{FAMACHA}^{\odot}\right)$ of ovine matrices in different physiological stages maintained in deferred pasture and supplemented with different protein sources.

\section{Body weight and body condition score}

There were significant differences in body weight $(\mathrm{P}=0.0475)$ and $\mathrm{BCS}(\mathrm{P}=0.0220)$ of the matrices supplemented with the different protein sources, the lowest values were observed in the animals that received coconut pie supplementation. The matrices supplemented with the other protein sources had similar body weight and BCS (Figures 3 and 4). The maternal body weight was higher during the final third of gestation, and decreased with physiological stages $(\mathrm{P}=0.001)$, regardless of the protein source used in the supplementation (Figure $3)$, while the BCS remained unchanged $(\mathrm{P}=0.2335)$.

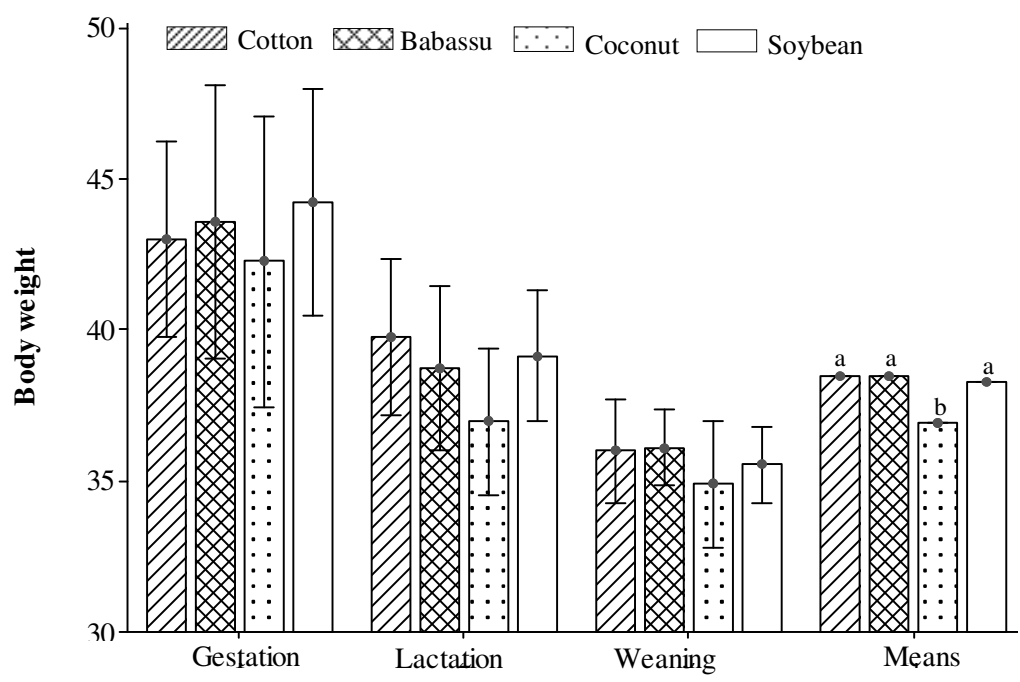

Figure 3. Body weight $(\mathrm{kg})$ of ovine matrices in different physiological stages maintained in deferred pasture and supplemented with different protein sources. Different letters differ between treatments $(P>0,05)$. 


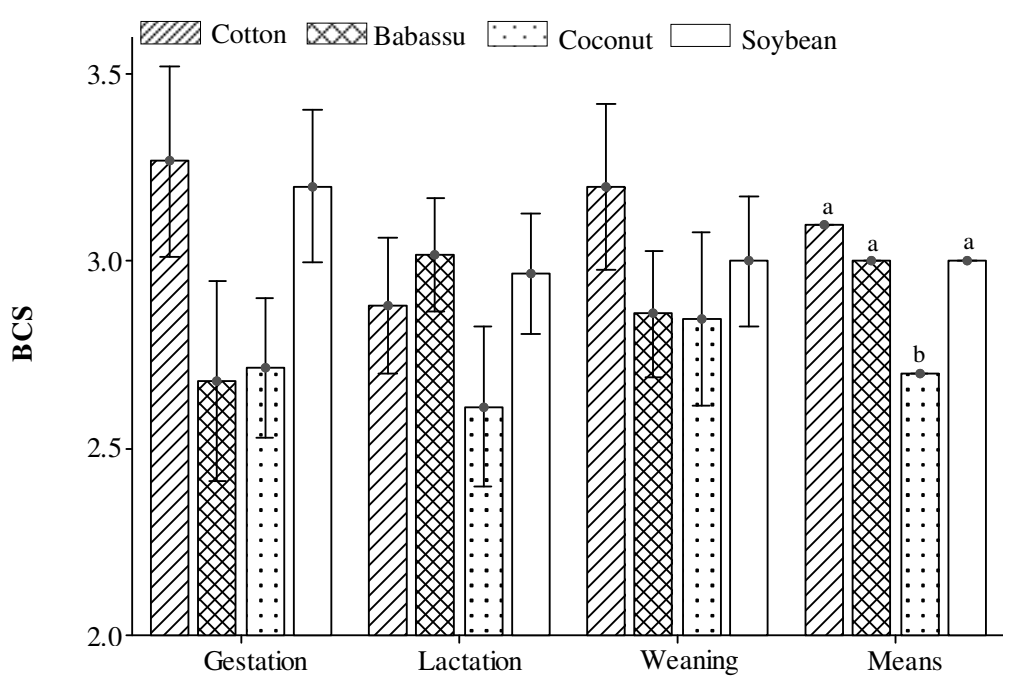

Figure 4. Body condition score (BCS) of ovine matrices at different physiological stages maintained in deferred pasture and supplemented with different protein sources.

Different letters differ between treatments $(P>0.05)$.

\section{Correlations}

Body weight correlated positively with BCS and negatively with FAMACHA $\odot$, which in turn correlated negatively with BCS (Table 3). EPG showed no significant correlation with live weight and BCS. The FAMACHA® degree had a positive and significant correlation with EPG.

Table 3. Pearson correlation coefficient between body weight (BW), body condition score (BCS), degree of anemia $\left(\mathrm{FAMACHA}^{\odot}\right)$ and eggs per gram of feces (EPG)

\begin{tabular}{lllll}
\hline & BW & BCS & FAMACHA $^{\odot}$ & EPG \\
\hline BW & 1 & & & \\
BCS & $0.3800^{*}$ & 1 & 1 & \\
FAMACHA $^{\odot}$ & $-0.1638^{*}$ & $-0.4012^{*}$ & $0.1519^{*}$ & 1 \\
EPG & $0.0432^{\text {ns }}$ & $0.0626^{\text {ns }}$ & & \\
\hline
\end{tabular}

* significant $(P<0.05)$; and ns: not significant, by the Pearson test.

\section{Biometric measurements of lambs}

Body length, chest width, croup width, and girth abdomen of lambs at 30 days of age were not affected by the protein sources of supplements offered to the matrices (Table 4). The height at withers and rump height limbs of the lambs at 30 days were higher $(\mathrm{P}<0.05)$ when the soybean bran was used in comparison to the coconut pie as a protein source in the supplement of the matrices. While the largest girth thoracic was observed with the use of soybean bran and cotton pie, and lower when using coconut pie.

Table 4. Means of biometric measurements $(\mathrm{cm})$ in vivo: in lambs from ewes supplemented with different protein sources.

\begin{tabular}{lllllll}
\hline Variables & Soybean & Babassu & Cotton & Coconut & SEM & P-value \\
\hline Body length & 37.2 & 36.2 & 36.2 & 34.9 & 0.56 & 0.5680 \\
Height at withers & $43.5^{\mathrm{a}}$ & $41.1^{\mathrm{ab}}$ & $40.6^{\mathrm{ab}}$ & $39.3^{\mathrm{b}}$ & 0.48 & 0.0453 \\
Rump height & $43.0^{\mathrm{a}}$ & $40.9^{\mathrm{ab}}$ & $39.8^{\mathrm{ab}}$ & $39.8^{\mathrm{b}}$ & 0.43 & 0.0367 \\
Chest width & 11.4 & 11.6 & 10.9 & 10.9 & 0.23 & 0.6735 \\
Croup width & 10.8 & 10.6 & 10.6 & 10.7 & 0.19 & 0.7431 \\
Girth thoracic & $48.8^{\mathrm{a}}$ & $47.8^{\mathrm{ab}}$ & $48.6^{\mathrm{a}}$ & $44.5^{\mathrm{b}}$ & 0.52 & 0.0241 \\
Girth abdomen & 50.1 & 50.3 & 51.6 & 46.9 & 0.66 & 0.7374 \\
\hline
\end{tabular}

Averages followed by distinct letters on the line differ between them by Tukey test $(P<0.05)$ SEM: Standard error of the mean. 
At 60 days postpartum, there was no effect of the protein sources of the matrix supplements $(\mathrm{P}<0.05)$ on the biometric measurements of the lambs. Lambs from the matrices supplemented with the coconut pie base protein presented lower biometric measurements at 30 days, but these differences disappeared until weaning at 60 days of age.

\section{DISCUSSION}

Our hypothesis is that the use of different protein sources in ovines matrices supplementation would be able to minimize the effects of parasitism. and that at least one of them could fully replace the soybean meal.

\section{Identification of infective larvae}

Costa et al. (2011); Costa et al. (2017); Melo et al. (2017) and Roberto et al. (2018), also described the high prevalence of Haemonchus spp. with values above $80 \%$ in the different populations of sheep studied. Haemonchus spp. is a hematophagous nematode that attaches mainly to the abomasal mucosa and sucks blood, an adult individual causes a removal around $0.05 \mathrm{~mL} /$ day $^{-1}$ blood (Roberto et al., 2018b), for this reason, therefore cause extravasation of epithelial cells, depending on the degree of infection, promote anemia, hypo-proteinemia, submandibular edema, and mortality. It is also considered the gastrointestinal nematode with the highest intensity of infection due to its hematophagous habit and presents high biotic potential (ROCHA et al., 2011; SANTOS et al., 2017).

\section{Egg count per gram of feces}

The different protein sources provided at the $0.5 \%$ level of live weight supplementation for gestation and lactation matrices do not present anthelmintic capacity. Rocha et al. (2011) also found no influence of protein supplementation at the end of gestation and lactation on the EPG count. The high endo-parasitic burden (Figure 1) shows that the matrices showed some degree of relaxation of the periparturient immunity (ROCHA et al., 2011; ROSALINSKI-MORAES et al., 2012; BEASLEY et al., 2012; JIMENEZ-SANZ et al., 2016).

In lactation, sheep matrices tend to be more susceptible to gastrointestinal nematodes due to increased demand for dietary metabolizable protein due to udder formation and lactic synthesis (ROSALINSKI-MORAES et al., 2012). Even the same, during the final third of gestation, these animals tend to be more resistant to endo-parasites. This fluctuation in the immunity of the matrices is known as a decrease in immunity in the peripartum (SHUBBER et al., 1981; BEASLEY et al., 2012), causing an increase in the number of eggs of helminths per gram of faeces (EPG) and of parasite burden during lactation (PINTO et al., 2008).

In this sense, Houdijk et al. (2009) reported that pregnant sheep supplemented with a diet rich in metabolizable protein had lower EPG counts than pregnant sheep supplemented with a diet low in metabolizable protein. However, compared to the sterile sheep, the supplemented ones still had 40 times more nematodes. These results indicate that, even when supplemented, sheep will undergo some degree of relaxation of periparturient immunity.

\section{Degree of anemia}

However, due to the lack of effect for EPG and FAMACHA $^{\odot}$ also was not altered (Figure 2), as there is a positive correlation between EPG and FAMACHA $^{\odot}$ (ROSALINSKI-MORAES et al., 2012, JIMENEZ-SANZ et al., 2016), especially since the main parasite affecting the herd is Haemonchus ssp. due to its hematophagous habit (ROCHA et al., 2011). The possible presence of resistant animals in the herd may have influenced the absence of effect of the physiological stages on the degree of anemia of the animals. Roberto et al. (2018) when evaluating the resistance and susceptibility to gastrointestinal nematodes in sheep on pasture did not observe a significant correlation between EPG and FAMACHA $^{\odot}$, the authors justified this fact to the great number of resistant animals.

\section{Body weight and body condition score}

The effect of protein sources on body weight and BCS (Figure 3 and 4) may be associated with the high ethereal stratum content of coconut pie (Table 2). Higher lipid intakes affect fiber degradability (RODRIGUES et al., 2018), increase rumen forage retention time, and promote consumption reductions. This effect may have been potentiated because pastures under deferred conditions present higher fiber contents (SANTOS et al., 2010).

The decrease in the body weight of the matrices with the passage of the physiological stages is expected because during gestation the weight of the matrix is increased with the weight of the fetus and the attachments and fetal fluids. This fact also justifies the behaviour of BCS, since weight loss during the physiological stages was not primarily due to the mobilization of body reserves 
Impact of supplementation...

and muscle tissue. Despite the high endo-parasitic burden, body weight and BCS behaved consistently with the physiological phase of the ewe, demonstrating that the protein sources used allowed a greater intake of nutrients and minimized the effects of the relaxation of the periparturient immunity.

\section{Correlations}

As the animal FAMACHA $^{\odot}$ increases, a reduction in $\mathrm{BCS}$ and body weight occurs (Table 3). BCS is a measure that indirectly evaluates the degree of deposition of tissues (muscle and adipose) in the animal, thus, as increases in tissue deposition are observed, a greater weight gain is observed too (MORTIMER et al., 2017).

In general, high endo-parasite burden is associated with poor performance (TORRESACOSTA et al., 2012; MELO et al., 2017). Even the same, it was observed that EPG did not correlate with BCS and body weight. This observation may be explained by the possible presence of resistant/resilient animals in the herd, since these animals tend to maintain the weight gain corresponding to the nutritional management offered to them, since they do not have or do, in a lesser extent, endo-parasites (AMARANTE et al., 2004; ROCHA et al., 2011; ROBERTO et al., 2018).

The high load of hematophagous endoparasites, being Haemonchus ssp. the most prevalent genus $(98 \%)$ in the herd promoted an increase in the degree of anemia in the matrices. Similar responses were reported by Abrão et al. (2010); Rosalinski-Moraes et al. (2012) and Jiménez-Sanz et al. (2016), although with stronger correlations, which reinforces the hypothesis of the presence of resilient animals in the herd. The average EPG of the matrices was 3476.0, and the animals were classified with FAMACHA $^{\odot} 2$ and 3 , and there was a sheep with 10.400 eggs/gram of
GURGEL, A. L. C. et al.

feces, which was classified with FAMACHA $^{\odot}$. In more extreme cases, animals with EPG of 20.000 were classified with FAMACHA $^{\odot} 2$ and 3.

\section{Biometric measurements of lambs}

Although there was no difference in the body length of lambs fed to matrices supplemented with different protein sources (Table 4), it is important to highlight that these averages predict the length of the loin and together with height and weight of the animal maintains the relation with the corporal conformation. The organoleptic characteristics of the coconut may explain the lower development of the biometric measurements of the offspring of the matrices that received the coconut pie supplement like a protein source in the first 30 days (Table 3). The presence of the endocarp allied to the high EE content may have affected digestibility and dietary intake, as early as 60 days of lamb life these differences disappeared. This result can be explained by the fact that with advancing age there is a reduction in the participation of milk in the diet of lambs, with this the consumption of concentrate ad libitum and the availability of forage results in the homogeneity of lambs at weaning.

\section{CONCLUSIONS}

Babassu, coconut and cotton pies, and soybean bran used as a protein source in the supplementation at $0.5 \%$ of the live weight for ovine matrices kept in the deferred pasture of Marandu grass maintain the production indexes consistent with the stage of the matrices, even with a high endo-parasitic burden.

Babassu and cotton pies can be used as a protein source in the supplementation of ovine matrices in replacement of soybean bran, as they allowed the performance of matrices and lambs equally to soybean bran.

RESUMO: O objetivo foi avaliar o impacto da suplementação com diferentes fontes proteicas da produção agroindustrial no perfil parasitológico das matrizes ovinas e no desenvolvimento de seus filhotes. As fontes de proteína utilizadas foram: farelo de soja, torta de algodão, torta de babaçu e torta de coco. Foram utilizadas 60 matrizes ovinas, com prenhez confirmada e suplementadas no terço final da gestação com 0,5\% do peso vivo em pastagens de capim Marandu diferido. As avaliações ocorreram desde o terço final da gestação e na fase de lactação até o desmame. Os dados coletados nas matrizes foram: contagem de ovos por grama de fezes (OPG) e identificação de larvas infectantes (teste fecal), avaliação do grau de anemia pelo método FAMACHA @, peso corporal (kg) e escore de condição corporal (ECC). Nos cordeiros, as medidas biométricas foram realizadas a partir dos 30 dias de vida até o desmame. No teste fecal, a prevalência foi de $98 \%$ de Haemonchus spp. Não houve efeito das fontes de proteína para OPG $(3476,0)$ e FAMACHA @. No entanto, nas matrizes suplementadas com torta de coco foram observados os menores pesos corporais $(36,9 \mathrm{~kg})$ e menor ECC (2,7). Torta de Babaçu, coco, algodão e farelo de soja utilizados como fonte protéica na suplementação de 
Impact of supplementation...

GURGEL, A. L. C. et al.

matrizes ovinas mantidas em pastos diferidos de capim Marandu no nível de $0,5 \%$ de peso vivo mantêm os índices de produção consistentes com o estágio fisiológico das matrizes, mesmo com uma carga endoparasitária alta.

PALAVRAS-CHAVE: Controle de helmintos. Nutrição. OPG. Ovinocultura. Periparturiente.

\section{REFERENCES}

ABDALLA, A. L.; SILVA FILHO, J. C.; GODOI, A. R.; CARMO, C. A.; EDUARDO, J. L. P. Utilização de subprodutos da indústria de biodiesel na alimentação de ruminantes. Revista Brasileira Zootecnia, v. 37, p. 260-258, 2008. http://dx.doi.org/10.1590/S1516-35982008001300030

ABRÃO, D. C.; ABRÃO, S.; VIANA, C. H. C.; VALLE, C. R. Utilização do método FAMACHA no diagnóstico clínico individual de haemoncose em ovinos no Sudoeste do Estado de Minas Gerais. Revista Brasileirade Parasitologia Veterinária, v. 19, n. 1, p. 70-72, 2010. http://dx.doi.org/10.1590/S198429612010000100014.

AMARANTE, A. F. T.; BRICARELLO, P. A.; ROCHA, R. A.; GENNARI, S. M. Resistance of Santa Ines, Suffolk and Ile de France lambs to naturally acquired gastrointestinal nematode infections. Veterinary Parasitology, v. 120, n. 2, p. 91-106, 2004. https://doi.org/10.1016/j.vetpar.2003.12.004.

BEASLEY, A. M.; KAHN, L. P.; WINDON, R. G. The influence of reproductive physiology and nutrient supply on the periparturient relaxation of immunity to the gastrointestinal nematode Trichostrongylus colubriformis in Merino ewes. Veterinary Parasitology, v. 188, n. 4, p. 306-324, 2012. https://doi.org/10.1016/j.vetpar.2012.03.022.

CEZAR, M. F.; SOUSA, W. H. Carcaças ovinas e caprinas: obtenção, avaliação e classificação. 1 ed. Uberaba, MG: Agropecuária Tropical, 2007. 147p.

COSTA, K. M. F. M.; AHID, S. M. M.; VIERA, L. S.; VALE, A. M.; SOTO-BLANCO, B. Efeitos do tratamento com closantel e ivermectina na carga parasitária, no perfil hematológico e bioquímico sérico e no grau Famacha de ovinos infectados com nematódeos. Pesquisa Veterinária Brasileira, v. 31, n. 12, p. 10751082, 2011. http://dx.doi.org/10.1590/S0100-736X2011001200007

COSTA, P. T.; COSTA, R. T.; MENDONÇA, G.; VAZ, R. Z. Eficácia anti-helmíntica comparativa do nitroxinil, levamisol, closantel, moxidectina e fenbendazole no controle parasitário em ovinos. Boletim de Indústria Animal, v. 74, n. 1, p. 72-78, 2017. https://doi.org/10.17523/bia.v74n1p72.

EMERENCIANO NETO, J. V.; DIFANTE, G. S.; LANA, A. M. Q.; MEDEIROS, H. R.; AGUIAR, E. M.; MONTAGNER, D. B.; SOUZA, J. S. Forage quality and performance of sheep in Massai grass pastures managed at pre-grazing canopy heights. South African Journal of Animal Science, v. 48, n. 6, p. 1073-1081, 2018. http://dx.doi.org/10.4314/sajas.v48i6.10.

FERNANDES, L. S; DIFANTE, G. S.; MONTAGNER, D. B.; EMERENCIANO NETO, J. V.; ARAÚJO, I. M. M.; CAMPOS, N. R. F. Structure of massai grass pasture grazed on by sheep supplemented in the dry season. Grassland Science, v. 63, n. 3, p. 177-183, 2017. https://doi.org/10.1111/grs.12165.

GAUDIN, E.; COSTES-THIRÉ, M.; VILLALBA, J. J.; HOSTE, H.; GERFAULT, V.; GINANE, C. Relative abilities of young sheep and goats to self-medicate with tannin-rich sainfoin when infected with gastrointestinal nematodes. Animal, v. 13, n. 7, p. 1498-1507, 2018. https://doi.org/10.1017/S175173111800304X.

GORDON, H. M. C. L.; WHITLOCK, A. V. A. New technique for counting nematode eggs in sheep feces. Journal of the Council for Scientific and Industrial Research, v. 12, n. 1, 50-52, 1939. 
Impact of supplementation...

GURGEL, A. L. C. et al.

HOUDIJK, J. G. M.; JACKSON, F.; KYRIAZAKIS, I. Nutritional sensitivity of resistance to Trichostrongylus colubriformis in lactating ewes. Veterinary Parasitology, v. 160, n. 4, p. 258-256, 2009.

https://doi.org/10.1016/j.vetpar.2008.11.013.

JIMÉNEZ-SANZ, A. L.; QUIRINO, C. R.; PACHECO, A.; COSTA. R. L. D.; BELTRAME, R. T.; RUA, M. A. S.; SILVA, R. M. C.; MADELLA-OLIVEIRA, A. F. Relação entre os fatores associados às parasitoses gastrointestinais, desempenho e estado fisiológico de ovelhas Santa Inês. Ciência Animal, v. 26, n. 2, p. 68-80, 2016.

KAHN, L. P.; KNOX, M. R.; GRA, Y. G. D.; LEA, J. M.; WALKDEN-BROWN, S. W. Enhancing immunity to nematode parasites in single-bearing Merino ewes through nutrition and genetic selection. Veterinary Parasitology, v. 112, n. 3, p. 211-225, 2003. https://doi.org/10.1016/S0304-4017(02)00438-7.

KEITH, R. K. The differentiation of infective larvae of some common nematode parasites of cattle. Australian Journal of Zoology, v. 1, n. 2, p. 223-235, 1953. https://doi.org/10.1071/ZO9530223.

MELO, G. K. A.; ÍTAVO, C. C. B. F.; MONTEIRO, K. L. S.; SILVA, J. A.; SILVA, P. C. G.; ÍTAVO, L. C. V.; BORGES, D. G. L.; BORGES, F. A. Effect of creep-fed supplement on the susceptibility of pasture-grazed suckling lambs to gastrointestinal helminthes. Veterinary Parasitology, v. 239, n. 3, p. 26-30. 2017. https://doi.org/10.1016/j.vetpar.2017.04.017.

MORTIMER, S. I.; HATCHER, S.; FOGARTY, N. M.; WERF, J. H. J.; BROWN, D. J.; SWAN, A. A.; GREEFF, J. C.; REFSHAUGE, G.; EDWARDS, J. E. H.; GAUNT, G. M. Genetic parameters for wool traits, live weight, and ultrasound carcass traits in Merino sheep. Journal of Animal Science, v. 95, n. 5, p. 18791891. 2017. https://doi.org/10.2527/jas.2016.1234.

NRC-National Research Council. Nutrient Requirements of Small Ruminants. 6. ed. Washington, D.C.: National Academy Press, 2007. https://doi.org/10.17226/11654.

PINTO, J. M. S.; OLIVEIRA, M. A. L.; ÁlVARES, C. T.; COSTA-DIAS, R.; SANTO, M. H. Relação entre o periparto e a eliminação de ovos de nematóides gastrintestinais em cabras Anglo Nubiana naturalmente infectadas em sistema semi-extensivo de produção. Revista Brasileira de Parasitololgia Veterinaria, v. 17, n. 1, p. 138-143, 2008.

ROBERTO, F. F. S.; DIFANTE, G. S.; ZAROS, L. G.; GURGEL, A. L. C. Nematoides gastrintestinais na ovinocultura de corte sob regime de pastejo. Pubvet, v. 12, n. 4, p. 1-12, 2018a.

https://doi.org/10.22256/pubvet.v12n4a65.1-12.

ROBERTO, F. F. S.; LIMA JUNIOR, V.; GURGEL, A. L. C.; SARAIVA, W. A.; SILVA, Y. M. O.; SILVA, L. R. C.; SILVA, L. A. C.; TEIXEIRA, A. C. Avaliação de resistência e susceptibilidade a nematódeos gastrintestinais em ovelhas a pasto. Boletim de Indústria Animal, v. 75, n. 1, p. 44-51, 2018b. https://doi.org/10.17523/bia.v75n1p44.

ROBERTS, F. H. S.; O'SULLIVAN, J. P. Methods for egg counts and larval cultures for strongyles infesting the gastrointestinal tract of cattle. Australian Journal of Agricultural Research, v. 1, n. 1, p. 99-102, 1950. https://doi.org/10.1071/AR9500099.

ROCHA, R. A.; BRICARELLO, P. A.; SILVA, M. B.; HOUDIJK, J. G. M.; ALMEIDA, F. A.; CARDIA, D. F. F.; AMARANTE, A. F. T. Influence of protein supplementation during late pregnancy and lactation on the resistance of Santa Ines and Ile de France ewes to Haemonchus contortus. Veterinary Parasitology, v. 181, n. 1, p. 229-238, 2011. https://doi.org/10.1016/j.vetpar.2011.03.055. 
RODRIGUES, J. P. P.; RAMIN, M.; HUHTANEN, P.; ARU, F.; DETMANN, E.; MARCONDE, M. I. Effect of soya bean oil supplementation and forage type on methane production and fibre digestibility using the in vitro gas production system. Grass and Forage Science, v. 73, n. 1, p. 368-380, 2018. https://doi.org/10.1111/gfs.12326.

ROSALINSKI-MORAES, F.; FERNANDES, F. G.; MUNARETTO, A.; OLIVEIRA, S.; WILMSEN, M. O.; PEREIRA, M. W.; MEIRELLES, A. C. F. Método Famacha $\odot$, escore corporal e de diarreia como indicadores de tratamento anti-helmíntico seletivo de ovelhas em reprodução Famacha $\odot$. Bioscience Journal, v. 28, n. 6 , p. 1015-1023, 2012.

SANTOS, M. E. R.; FONSECA, D. M.; BALBINO, E. M.; SILVA, S. P.; MONERAT, J. P. I. S. Valor nutritivo de perfilhos e componentes morfológicos em pastos adubados com nitrogênio. Revista Brasileira de Zootecnia, v. 39, n. 9, p. 1919-1927, 2010. http://dx.doi.org/10.1590/S1516-35982010000900009.

SANTOS, M. E. R.; CASTRO, M. R. S.; GOUVÊIA, S. C.; GOMES, V. M.; FONSECA, D. M.; SANTANA, S. S. Contribuição de perfilhos aéreos e basais na dinâmica de produção de forragem do capim-braquiária após o pastejo diferido. Bioscience Journal, v. 30, n. 3, p. 424- 430, 2014.

SANTOS, J. M. L.; VASCONCELOS, J. F.; FROTA, G. A.; RIBEIRO, W. L. C.; ANDRÉ, W. P. P.; VIEIRA, L. S.; TEIXEIRA, M.; BEVILAQUA, C. M. L.; MONTEIRO, J. P. Haemonchus contortus $\beta$-tubulin isotype 1 gene F200Y and F167Y SNPs are both selected by ivermectin and oxfendazole treatments with differing impacts on anthelmintic resistance. Veterinary Parasitology, v. 248, n. 1, p. 90-95, 2017.

https://doi.org/10.1016/j.vetpar.2017.11.003.

SHUBBER, A. H.; LLOYD, S.; SOULSBY, E. J. L. Infection with gastrointestinal helminths. Effect of lactation and maternal transfer of Immunity. Zeitschrift für Parasitenkunde, v. 65, n. 2, p. 181-189, 1981. https://doi.org/10.1007/BF00929184

THORTHWAITE, C. W. An approach toward a rational classification of climate. Geographic Review, v. n. 1, p. 38, 55-93, 1948. https://doi.org/10.2307/210739

TRINDADE, T. F. M.; DIFANTE, G. S.; EMERENCIANO NETO, J. V.; FERNANDES, L. S.; ARAÚJO, I. M. M.; VERAS, E. L. L.; COSTA, M. G.; SILVA, M. G. T.; MEDEIROS, M. C. Biometry and carcass characteristics of lambs supplemented in tropical grass pastures during the dry season. Bioscience Journal, $\mathrm{v}$. 34, n. 1, p. 172-179, 2018. https://doi.org /10.14393 / BJ-v34n1a2018-36781.

TORRES-ACOSTA, J. F. J.; SANDOVAL-CASTRO, C. A.; HOSTE, H.; CABELLERO, A. J.; SARMIENTO, C. R.; ALONSO-DÍAZ, M. A. Nutritional manipulation of sheep and goats for the control of gastrointestinal nematodes under hot humid and subhumid tropical conditions. Small Ruminant Research, v. 103, n. p. 28-40, 2012. https://doi.org/10.1016/j.smallrumres.2011.10.016

VAN WYK, J. A.; BATH, G. F. The Famacha@system for managing haemonchosis in sheep and goats by clinically identifying individual animals for treatment. Veterinary Research, v. 33, n. 1 509-529, 2002. https://doi.org/10.1051/vetres:2002036 